Received 17.06.2017

Reviewed 24.06.2018

Accepted 03.08.2018

A - study design

B - data collection

C - statistical analysis

D - data interpretation

E - manuscript preparation

F - literature search

\title{
Correlating soil and urban planning for sustainable water cycle
}

\author{
Sheetal SHARMA ${ }^{\text {ABCDEF } \triangle}$
}

orcid.org/0000-0002-7046-0796; Laxmi Narayan College of Technology University, School of Architecture, Sarvadharma C Sector, Kolar Road, 462016 Bhopal, Madhya Pradesh, India; e-mail: sheetalsharmaplanner@gmail.com

For citation: Sharma S. 2019. Correlating soil and urban planning for sustainable water cycle. Journal of Water and Land Development. No. 40 (I-III) p. 137-148. DOI: 10.2478/jwld-2019-0015.

\begin{abstract}
Hydrological modelling and processes using modern hydrological models like SCS Curve Number, HCS, HSPF (Hydrologic Simulation Package-Fortran) and kinematic wave models are widely used nowadays in various researches. But using these modelling in drawing the attention of urban planners for challenges and multiple interactions in heterogeneous urban catchments and water systems is still a shortcoming in water sensitive, planning principle. The art of urban planning and technical implementation using behavioural changes in water responses to urban catchments is the need of present urban planning. The complexities of effects and behavioural changes in the water system or urban catchments and incomplete knowledge of these interactions result in failures of sustainable urban developments. Urban planning needs water sensitive methodology to synchronize soil, water and land cover operational with the population over it. The paper reviews the water sensitive urban planning considering the role of soil in urban planning for water and lands correlations, with the purpose of identifying current limitations and opportunities for future urban planning.

Data availability and simplified methods are still a strong limitation for urban planners. Therefore, urban hydrology is often simplified either as a study of surface runoff over impervious surfaces or hydraulics of piped systems. Hence the paper provides approach and universal solution to forecast the behaviour of urban catchment for urbanization in terms of natural land-water cycles and its application in planning existing or new urban catchments. The methodology consists of observing Urban watershed catchment areas with different soil groups and built-up induction over them. A detailed study of water levels in hydrological wells and runoff pattern for the period of 40 years have provided a linear correlation of soil, roughness, land cover, infiltration, ground water and built upon the basis of soil behaviours. These correlations conclude to make regression equations as the blueprint for future urban planning norms to be followed by the planners, engineers, and hydrologists for planning.
\end{abstract}

Key words: geology, land use-land cover, runoff, sustainable water cycle, urban planning

\section{INTRODUCTION}

Water scarcity, is becoming a burning issue in most of the cities and countries. Precipitation pattern is also showing a temporal variation in its behaviour. Rising temperatures are accelerating the hydrological changes, causing rivers and lakes to freeze/dry in repeated cycles [UNESCO 2006]. Human activities and urbanization are likely to affect climate change which in result will impose extreme challenges and risks in resource management [GLEICK et al. 2011].
Government is and has to be conferenced about upcoming challenges in developing and monitoring urbanization and its forthcoming effects on land and water [ARNOLD et al. 1998; FLETCHER et al. 2013]. Land use policies and effects need a careful combination of planning and natural science for the sustainable water cycle [MONK 2006].

Society suffers yearly from the consequences of (flash) floods, with mortality nearly homogeneous over different continents Water movement in urban areas is however not well understood, and so are the physical principles that 
regulate this movement as well as the interactions occurring between the hydrological processes [CHANG, JUNG 2010]. Scientific understanding can be supported by detailed and consistent measurements and by hydrological modelling, therefore urban hydrology will be an issue in the decades ahead [ELGA et al. 2015].

Most of the studies are related to urban water contamination and piped water for cities, leading to more of urban design solutions rather than urban planning [GORMLEY 2009]. Planning is for future and designs are for the present. So dealing future in respect of water sensitive planning is need and priority for the government policies all around the world [GORMLEY 2009].

This paper is based on observations of urban catchments developing from natural to urbanized state and the behavioural changes in runoff and recharge in context of geology below and land cover. The methodology involved the comprehensive analysis of urban catchments transmuting from environmental to urbanized either abruptly without proper planning or progressively having norms and rules monitored [SHARMA, BHARAT 2011]. Land use policies and guidelines for physical development and their shortcomings in assuring land cover with open spaces were compared with existing built-up and runoff. Role of soil in concluding the built-up or land cover was a prime benchmark added the findings for deriving equations as a tool for planners in adjudicating the upcoming master plan interpretations and implementations [SOLOMON et al. 2007; UNESCO 2006].

The circulation of rainwater within urban areas has not yet been described in a detailed manner, as studies on this topic often remain limited to the runoff on impervious surfaces [HAMDI et al. 2011]. Developments in this direction generally focus either on very specialized tools for design solution in mathematical model or policy guidelines for several semi-specialized components to describe the total water cycle in urban areas [SALVADORE et al. 2015].

To maintain the balance between ever dynamic, population increase and the decrease of underground water availability, the gap between the increase in population resulting in more built-up areas and effects of land cover on soil need to be studied.

\section{STUDY METHODS AND AREA}

\section{THE METHODOLOGY ADOPTED FOR HYDROLOGICAL MODELLING}

Figure 1 depicts the broad methodology adopted to observe the correlations between soil, development and water. The study was carried out by observing individual systems first and then their interactions with other systems with most affecting variables. Urbanization, soil properties and water moisture content with water table variations were most observed parameters for a span of 40 years to get correlations among systems.

The methodology thus assesses the status of urban hydrological modelling by analysing: the spatial and temporal scale of selected urban catchments with the use of GIS and remote sensing for land cover, the flow routing options of stream and surface flow, the advances in geologically-based behaviour of the urban water system and how

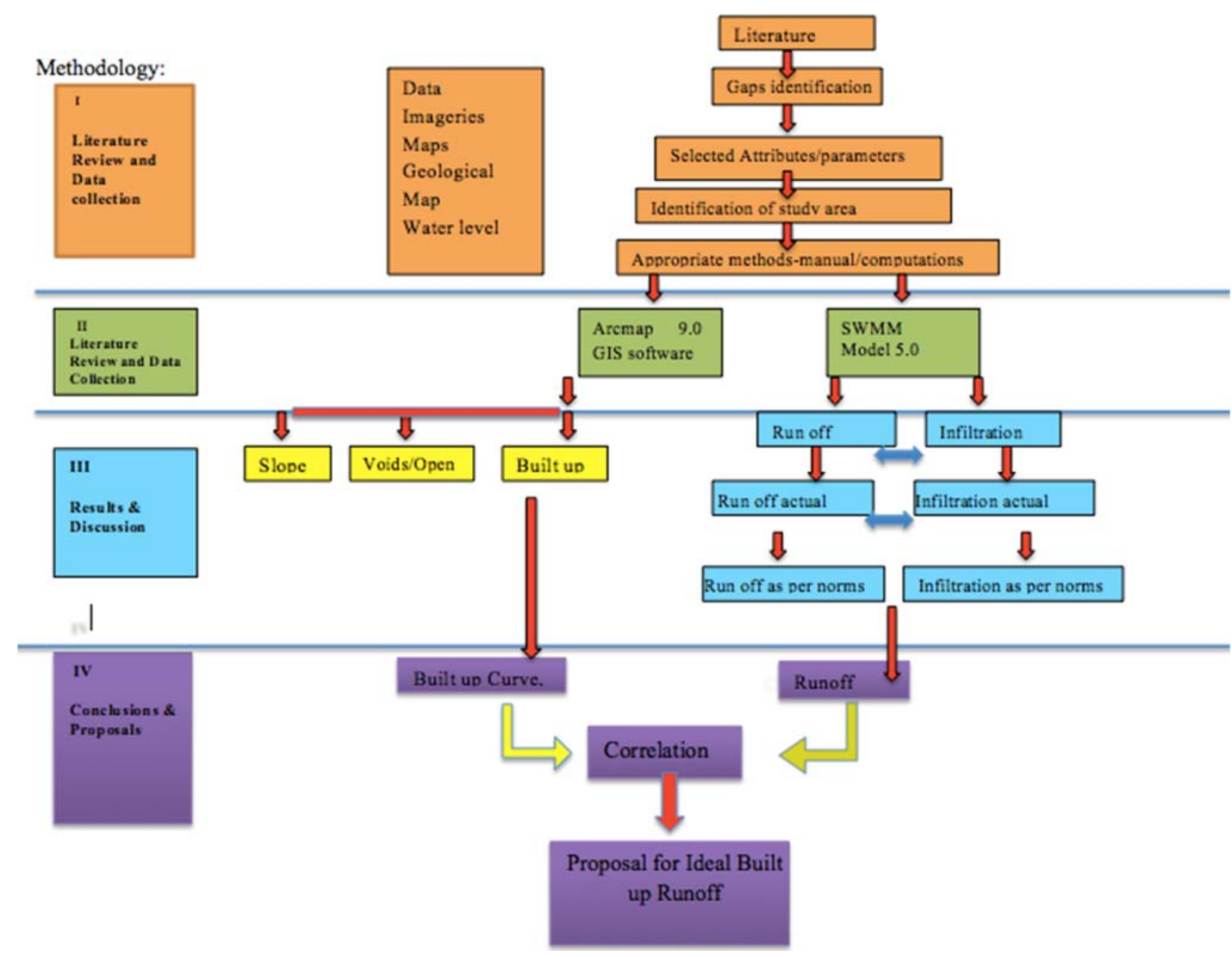

Fig. 1. Methodology for hydrological modelling; source: own elaboration 
parameters are estimated and models evaluated based on land use guidelines, their implementation, and ignorance [LEE, HEANEY 2003]. To do so, we compared 19 models and modelling strategies described in 27 publications in the period 1974-2011 for an urban area of 55 ha with three soil groups and heterogeneous nature of development.

Accordingly, a basic model of the study area in Bhopal city was built in SWMM 5.2, using the Arc GIS with the integration of different land cover roughness layers for different time periods. The precipitation data obtained from the Meteorological Department and the report of Water Resource Department [CGWB 2010; CWC 1988] for the normal rainfall series and the critical rainfall series were added. AutoCad Civil 3D software was used to categories sub-catchments on basis of Digital Elevation Model (DEM) and contours of Google surface to facilitate analysis of surface flows. Then the natural drainage paths and the man-made conduits along with the junctions and nodes were formed in the Storm Water Management Model (SWMM). The sub-catchments were assigned respective geological properties based on soil and the related properties for length, width, slope, impervious \% and roughness, flow routing, inflows, dry weather inflows, etc. were added [ARNOLD et al. 1998]. The outlets and conduits were assigned properties such as circular pipe, trapezoidal, natural etc. for natural drainages as well as man-made. Manning $n$ for the concrete pipes and the natural rain gauges were assigned. The storage units and the aquifers were assigned data as per hydrogeology reports.

Based on observations for better results by HAMDI et al. [2011] catchment size was taken more than 10 hectares divided them into grid-based, which include all the other categories of sub-catchments or urban hydrological elements. Time zone selected was based on the hourly basis of 24-hour observation and long-term temporal scale of 40 years for the accuracy of observations in kinematic/diffusive/dynamic subsurface and surface flow, shallow water equations, and groundwater prospects [SHARMA, BHARAT 2011].

Simulation results obtained were in the form of the catchment area, precipitation, roughness value, infiltration value, runoff value, evapotranspiration value and evaporation value for given precipitation and time interval using the modelling procedure in Table 1.

The two methods for simulation used were:

- by keeping precipitation and slope, width constant for respective years,
- by changing precipitation on the hourly and daily basis to observe long-term runoff changes and short-term peak flow changes.

Model results obtained were tested for accuracy by regression model and the difference between observed and simulated hydrographs were checked for least error [ARNOLD et al. 1998; GORMLEY 2009]. The runoff changes for constant precipitation with changing built-up were analysed first. The combinations of inter location runoff and the intra location runoff were used to form the correlation equation and the constants $\left(y=a x^{2}+b x+c\right)$ where $y$ is the runoff and $x$ are built-up. The correlation observations for each catchment for each decade was plotted to see the trend line and the resulting equation. To calibrate the hydrologic model the land use/land cover (LULC) data was prepared in an $8 \mathrm{~m}$ grid. The time series data was made for hourly rainfall event. Finally, the simulation was run for different years as per conditions prevailing for that specified times and the continuity errors as well as flow routing errors were minimized to get accurate results [LEE, HEANEY 2003]. The obtained report of the rainfall runoff was then observed and compared to viewing results and changes in the parameters. The correlation analysis was performed to obtain a correlation and best-fit method was used to get the minimum error value [KARMAKAR undated]. The correlation thus formed was observed for various catchments individually i.e. inter location and then with others with same characteristics over all the study area i.e. intra location.

The simulation was run with following time series:

i) critical rainfall-runoff analysis from June to September with the temporal scale of 40 years,

ii) critical rainfall-runoff analysis for peak hour (24 h) hourly basis,

iii) rainfall-runoff analysis with varying precipitation,

iv) rainfall-runoff analysis for built-up as per rule and built-up as per actual (policy guidelines).

\section{BASIC CHARACTERISITCS OF STUDY AREA - BHOPAL (INDIA)}

The study area selected covers two urban areas constituting several wards of Bhopal District, State Madhya Pradesh, and Country India. Figure 2 as per Centre Groundwater Board [CGWB 2014]. The areas selected have two different urban catchment forms. One with developing the character with specific geological setup and other with de-

Table 1. Modelling procedure adopted

\begin{tabular}{|c|c|c|c|c|c|c|}
\hline $\mathrm{Sn}$ & Scenario & Varying parameter & Constant & Observation & Result & $\begin{array}{c}\text { Equation } \\
\text { as in Tab. } 4\end{array}$ \\
\hline 1 & actual scenario & increasing built-up & constant precipitation & individual catchment & runoff & 1 \\
\hline 2 & policy guidelines & built-up as per municipal by laws & constant precipitation & individual catchment & runoff & 2 \\
\hline 3 & climate & precipitation & built-up & individual catchment & runoff & 3 \\
\hline \multirow[t]{2}{*}{4} & land cover and geology & roughness - land cover & precipitation & group of catchment as per geology & runoff & 4 \\
\hline & \multicolumn{5}{|l|}{ final equation } & A \\
\hline 5 & validation & roughness & precipitation & alluvial catchment & runoff & B \\
\hline 7 & validation & roughness & precipitation & basalt catchment & runoff & $\mathrm{D}$ \\
\hline
\end{tabular}

Source: own elaboration. 


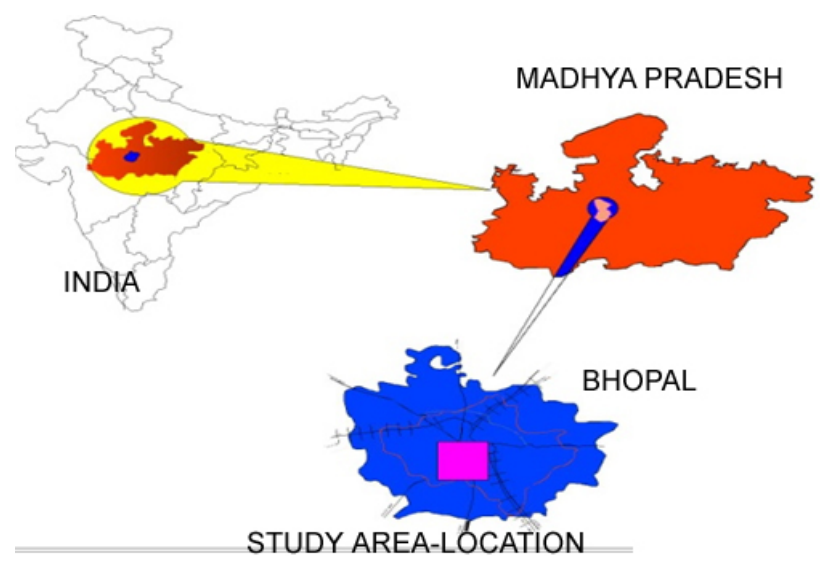

Fig. 2. Bhopal city; source: own elaboration

veloped character and different geological set-up. Both areas have recently been facing water level drop; one has a recharge zone character and other has discharge zone character. The wards coming within these natural boundaries have been taken for observation and analysis. It consists of Area Colony, Shahpura, Chunabhatti, and Manit. The study area comprises of natural drainage of Kaliasot River along with Kaliasot dam, Bhadbhada area (soil way of Upper Lake), southern portion of Upper Lake, hills like Samasgarh, forest areas near Chichli, Nayagoan. The study area spreads over 117800 ha. It covers the major portion of urban areas some developed according to physical planning aspects whereas some developed drastically in short span, of the Bhopal district (M.P.). It refers to survey of India Toposheet No. $55 \mathrm{E} / 8$ and bounded by latitudes $23^{\circ} 10^{\prime}$ to $23^{\circ} 15^{\prime} \mathrm{N}$ and longitudes $77^{\circ} 23^{\prime} 30^{\prime \prime}$ to $77^{\circ} 27^{\prime} \mathrm{E}$.
The watershed map of Bhopal (1990), in which different catchment was identified for analysis of water prospect map and hydrogeology wells (Fig. 3, 4) of the city for maximum recharge potential and areas experiencing the sudden decline in the water table. Some areas, which had been showing satisfactory reactions to urbanization processes, were also selected to observe the basic factor underlying their performance in natural as well as urban cycle. Also, the ward map (localities demarcated as wards by Bhopal Municipal corporation at local level plan) for the same area was obtained to ascertain the areas already developed and areas still developing.

Basic characteristics. Along with this CGWB report [CGWB 2014], critical water tables in the city were identified. As per the secondary data, it was found after analysis that some areas have been critical for water table fluctuation and some had shown improvement. The areas were marked as per the hydrogeology wells location. Water prospects of the study areas which were sensitive to water development and the areas which have great natural potential or carrying capacity were highlighted such as catchments named BSHC, BOBC, BOCC (catchment names as per nomenclature use by $\mathrm{CGWB}$ ) and catchments with poor water prospects such as BSHC (upper part), BOBC - lower part and BLPC.

- Vindhyan sandstone and basalts of the Deccan Trap underlie the area,

- promising aquifer zones cited in the Vindhyan within a depth range of 60-70 $\mathrm{m}$ b.g.l. especially at the base of Vindhyan hillocks or under a cover of weathered basalt,

- weathered and vesicular basalts also form potential aquifers.

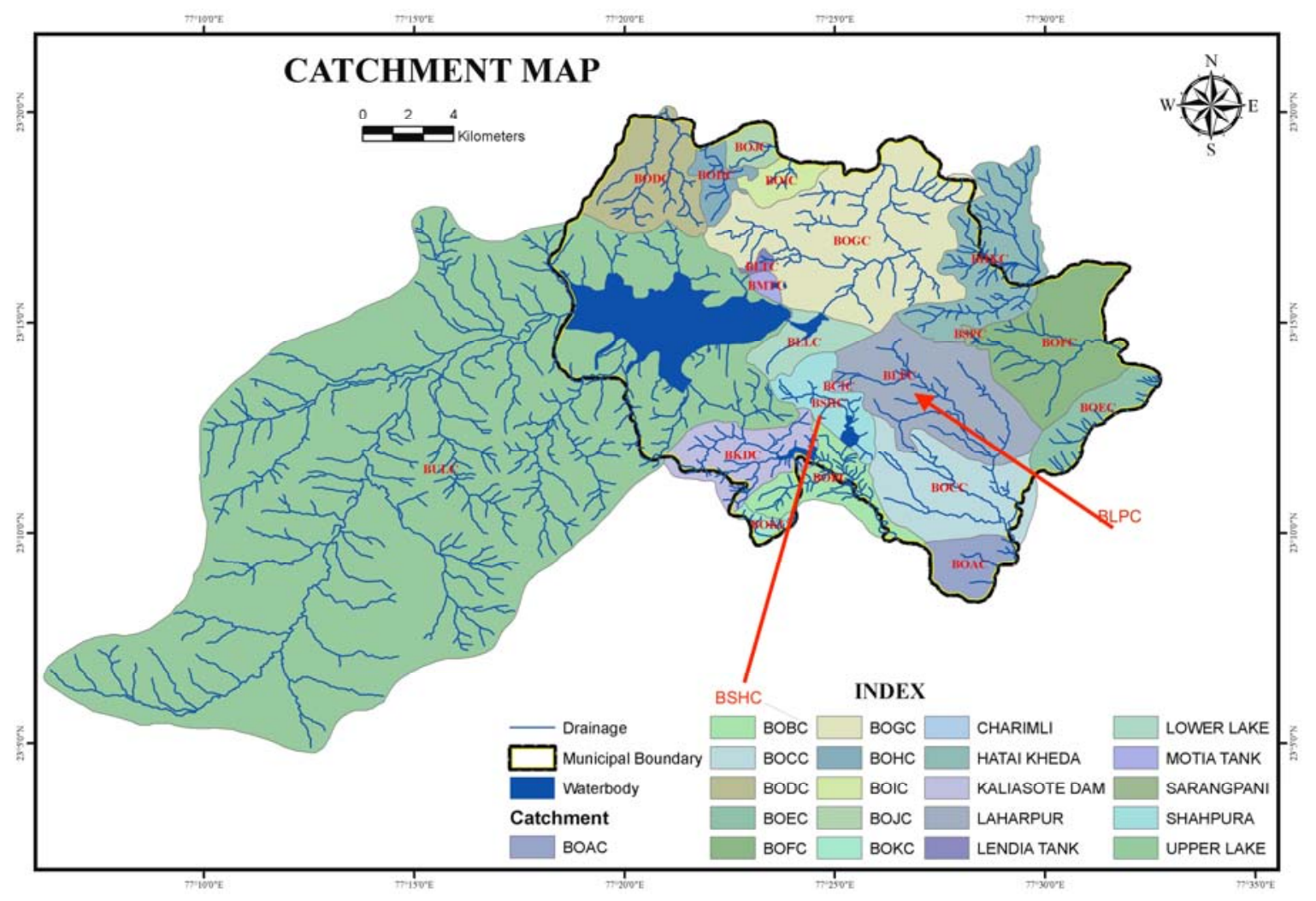

Fig. 3. Catchment map for Bhopal District; source: CGWB [2014] 


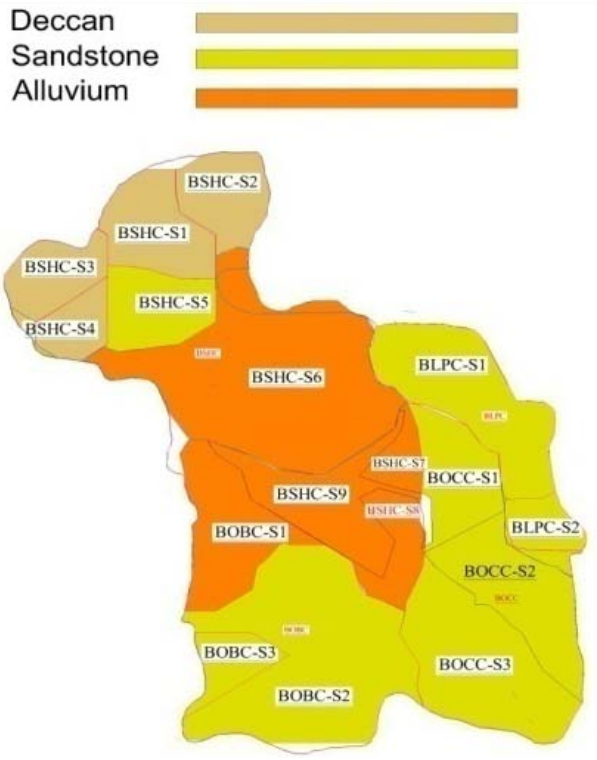

Fig. 4. Sub-catchment division of study area as per geology; source: own elaboration

State groundwater report for declining water levels:

- SGWB has marked Bhopal District as semi critical zone for declining water levels in recent years. Whereas Bhopal is called the city of lakes where 17 lakes had been existing since historical times. Only in recent time, it had been facing a sudden decline in water levels. The year 2009 was considered worse for Bhopal as its famous lake dried to $3 \%$ of its catchment area from 36 $\mathrm{km}^{2}$ to $5 \mathrm{~km}^{2}$.

- As per the report of the groundwater levels in District Bhopal, Madhya Pradesh (in meters b.g.l.) for Phanda, Berasia blocks. 1999, the Phanda block of the city has been identified as the semi-critical zone for the groundwater development in 2009-2012 (Centre Ground Water Board n.d.) [CWC 1988]. Along with this CGWB report for critical water tables in the city were identified. And catchment map was obtained from SGWB (State Ground Water Department).

- As per the secondary data, it was found after analysis that some areas have been critical for water table fluctuation and some had shown improvement. The areas were marked as per the hydrogeology wells location.

Geology of study area. The geological map obtained from the geological survey of India was observed for the geology of these catchments and the different soil layers under these catchments. The hydrogeology characteristics of the area were determined. The site has been divided into different sub-catchments depending upon the hydrogeology and the water flow pattern as shown in Figure 4 and Table 2 [Agvise Laboratories 2001; KARMAKAR undated).

Geological map of study area - subdivided as per catchments (Fig. 5).

Modelling parameters. Modelling parameters considered consist of soil group, SCS curve number, Manning $n$, slope, roughness, land cover, land use, rainfall on hourly basis and monthly basis, peak rainfall, built up and open areas, vegetation, concrete, shrubs and forest roughness values for runoff coefficient. Modelling procedure is mentioned in Table 2.

\section{RESULTS}

Land cover changes from 1974 to 2013. Built-up changes in chronological order for the study area are shown in Figure 6.

Catchment wise changes in land use: from above charts. Catchments have observed variations in development since 1974 where some areas experienced commercial development more than 55\% and some had residential development more than $80 \%$. Sub Catchments as divided in Figure 4 like BSHC-S5, BSHC-S6 and BSHC-S8 have contrasting development though being adjacent where BSHC-S6 and BSHC-S8 retained most of the green cover but BSHC-S5 was suddenly commercialized in span of 10 years reducing green cover content by more than $40 \%$. Catchment BHSC-S1 and BHSC-S2 experienced balanced development with grid iron planning and moderate plot sizes, where as BOCC-S2 and BOCC-S1 have colonies with very small plot sizes and a dense residential unit developed over it. BCIC catchment has linear gardens with large open spaces.

Built-up variation and runoff with Built up variations in the study area is shown in Figures 6 and 7 in percent during the period of 1974 to 2012.

Water level variations as per Centre Groundwater report: 40 years record.

- Well in sandstone area (1984-2012)

- BPL-011-Misrod

Situated in outskirts of the study area and on Hoshangabad highway this area has shown a continuous decline in water levels since 1990 onwards and have been declared as a critical zone by SGWB. The water level has dipped about $12 \mathrm{~m}$ below ground level (m b.g.l.).

Table 2. Geological characteristics of study area

\begin{tabular}{|l|l|l|l|}
\hline \multicolumn{1}{|c|}{ Zone } & \multicolumn{1}{|c|}{ Lithology } & \multicolumn{1}{c|}{ Characteristics of soil } & \multicolumn{1}{c|}{ Groundwater potential } \\
\hline Quaternary to recent & alluvium & $\begin{array}{l}\text { nearly impermeable with } \\
\text { tiny pores }\end{array}$ & $\begin{array}{l}\leq 2 \text { unconsolidated, primary porosity } \\
\text { (areas - Chunabhatti) }\end{array}$ \\
\hline $\begin{array}{l}\text { Upper Cretaceous to } \\
\text { Eocene }\end{array}$ & $\begin{array}{l}\text { Deccan trap (porosity 0.65\%) } \\
\text { absorption \% }=0.33-2.43\end{array}$ & $\begin{array}{l}\text { good aquifers occur in this } \\
\text { zone }\end{array}$ & $\begin{array}{l}\text { 1-5, secondary porosity, fractured horizons, interflow contacts } \\
\text { and vascular basalt } \\
\text { (areas - Shahpura, area region) }\end{array}$ \\
\hline Upper Protozoan & $\begin{array}{l}\text { sandstone } \\
\text { absorption }=0.004-0.12\end{array}$ & weathered and porous zone & $\begin{array}{l}\text { 1-3, secondary porosity, jointed and fractured horizon } \\
\text { (areas - South Tatya Tope Nagar, North Tatya Tope Nagar, } \\
\text { Shivaji Nagar, part of Arera Colony) }\end{array}$ \\
\hline
\end{tabular}

Source: own elaboration based on GSI Map of Bhopal data, Figure 5. 


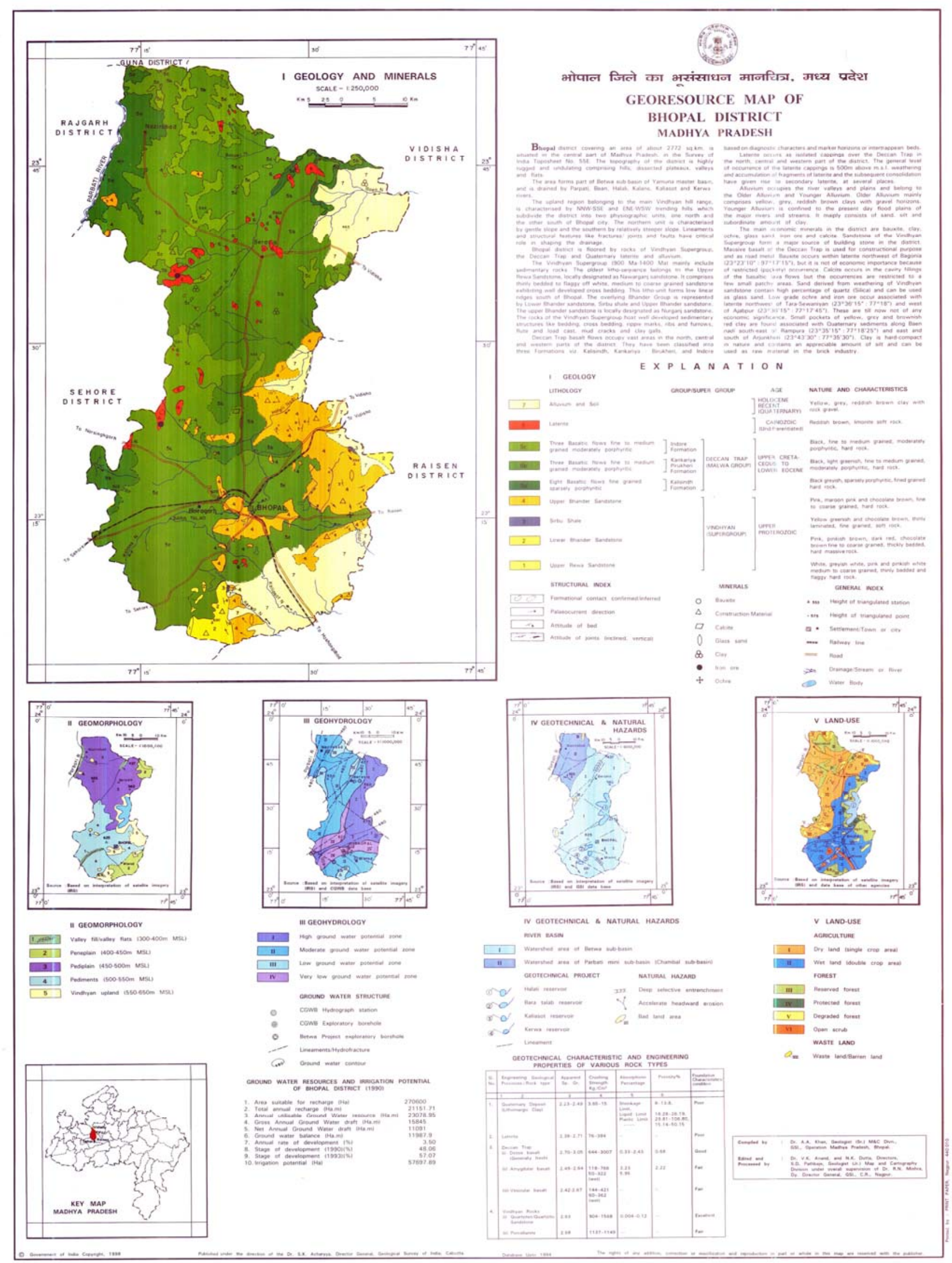

Fig. 5. Hydrogeology map - Bhopal; source: Bhopal District 


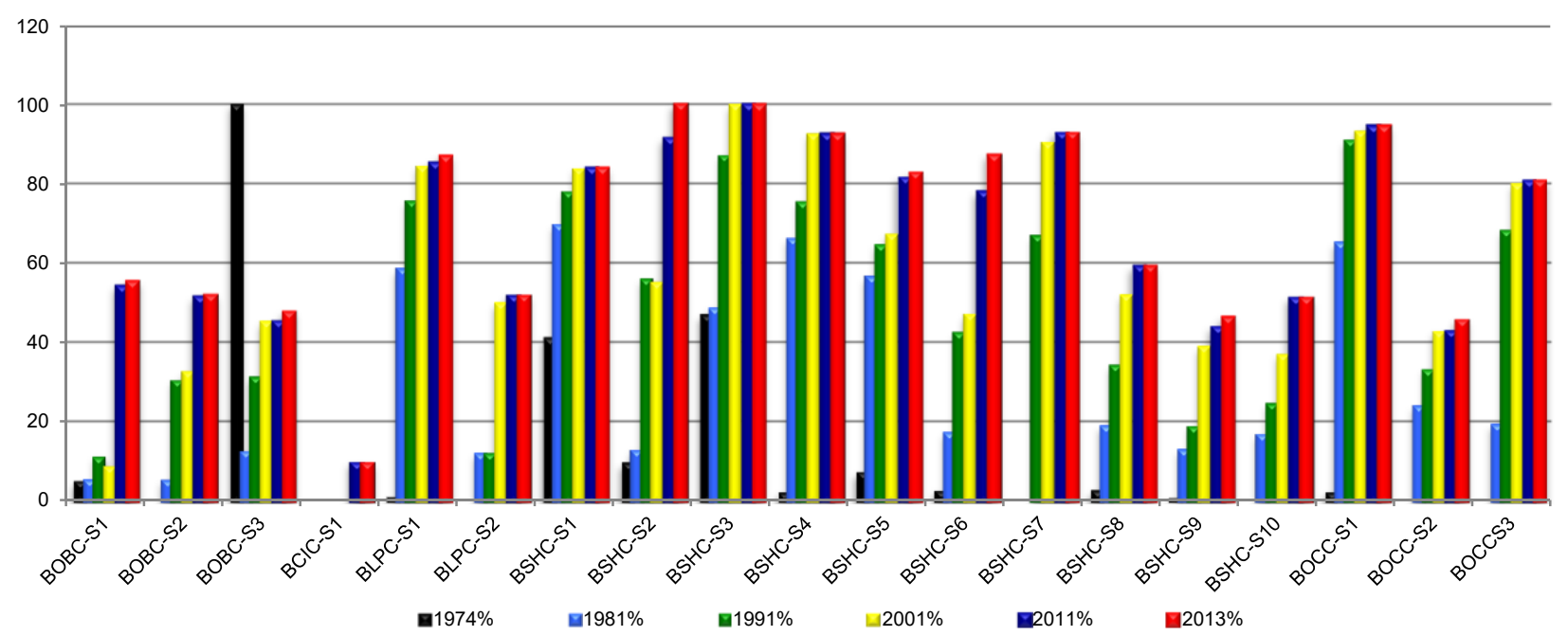

Fig. 6. Built-up in urban catchment from 1974 to 2013; descriptions of catchments as in Fig. 4; source: own study

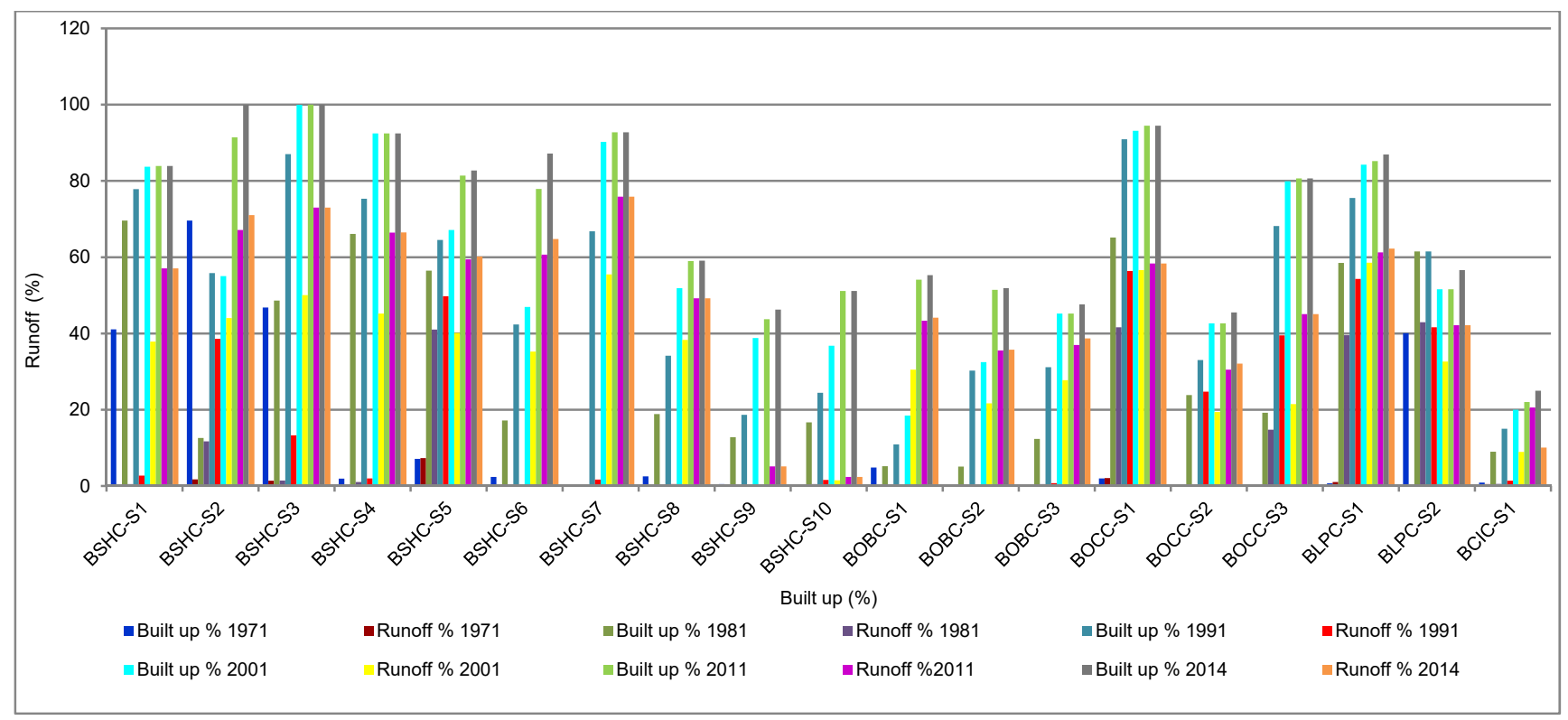

Fig. 7. Built-up and runoff variations from 1974 to 2013; descriptions of catchments as in Fig. 4; source: own study

Decrease in water level equal $6 \mathrm{~m}$

- Well in basalt soil area

Decrease in water level equal $8 \mathrm{~m}$

Water level - Ratibad (BPL-015)

This well has revealed the fact that though it lay within the catchment area of the upper lake, its recharge value has been constantly affected since 2009 onwards. The well had been functioning well before 2009. On the survey, it was found that about 18 colonies have been developed in this area from 2008 onwards and built-up have increased to $55 \%$ from $9 \%$ in 6 years.

- Well in alluvium soil

Decrease in water level equal $2 \mathrm{~m}$

Water level in hydrological wells set by State Ground Water Board in various areas - Bagh Mughaliya (well no. BPL020). The well is located in the flood zone of South Bhopal and has shown better water results since 1994 when the second master plan was implemented with land use change as floodplain and restricted construction around natural waterways. The well has experienced water level of $4 \mathrm{~m}$ b.g.l. post monsoon to $9 \mathrm{~m}$ b.g.l. in the pre-monsoon period with the fluctuation of $5 \mathrm{~m}$ in a year.

Water level - Akbarpur (well no. BPL045). This well is just to another well in Akbarpur by CGWB and is in the area reserved as flood affected area by the Bhopal Masterplan 1991. It has shown improvement in recharge but also same time has been experiencing declining water levels in pre-monsoon period up to $8 \mathrm{~m} \mathrm{b.g.l.}$

Water level - Ahmedpur (well no. BPL021). This well is located in a rocky area of south Bhopal where Deccan trap soil is available in the compact layer. The slope is towards the canal flowing nearby with barren land around. The well has poor performance with only $4-6 \mathrm{~m} \mathrm{b.g.l.} \mathrm{for}$ the year.

The observed changes in water levels obtained from State Groundwater Department were compared with the catchment results of runoff and the relative recharge and discharge levels of these were studied. Also, the catch- 
ments were observed with colony level water flows by photographs and videos.

The observations of comparative charts were analysed by simulation results obtained from SWMM model. Observations were based on comparative charts, regression analysis and minimum error check for the results.

The well water levels for last 40 years were compared to the infiltration and runoff results in Table 3 , assuming the recharge from other sources as constant. Only the infiltration from rainfall was considered to be a prime factor for the increase in level. This helped in comparing years and water levels in catchments with real-time water level and simulated infiltration in accordance with runoff and land cover roughness.

The observations were tabulated to form groups of well recharges areas and low recharge areas.

Intra location analysis: roughness, soil, runoff and infiltration behaviour of catchments: soil based hydrological modelling.

Observations for roughness and runoff land covers with different roughness and their response to urbanization are shown in Table 3.

Observations of different catchments and land covers show that the catchments having a land cover with roughness values ranging from 0.011 to 0.013 had no very less infiltration and most runoff due to the absence of vegetation. Similarly, concrete and dense bushes showed slightly better behaviour in catchments BSHC-S4, BLPC-S1 etc. Grass and mud surfaces helped more in reducing the runoff intensity and thus helped satisfactory infiltration also. Dense bushes and natural soil conditions were best to protect natural cycle of water with least runoff and most infiltration [BELLO et al. 2017; GRZYWNA, SENDER 2017].

The roughness values, land cover and the geology when compared together with runoff pattern it is clear that alluvial soil when subjected to dense bushes and natural soil cover assures the best working of a natural cycle. Since urbanization does not support this combination all over, it can be planned at some pockets of the urban area having alluvial soil as the geological base [FLETCHER et al. 2013]. Similarly, sandstone is good in fast infiltrating the runoff water with the help of grass and medium vegetation land cover. Basalt shows some scope of infiltration if land cover imposed on it is a dense bush or forest. Hence city parks and natural drainages with basalt base should be landscaped with dense bushes. Land cover with scanty grass and concrete does not support infiltration to a satisfactory level and hence development should be proposed such pockets with impervious base and least grass or natural cover [KJELDSEN et al. 2005]. These observations help to decide the planning perspective based on geology and land cover. This perspective can be further confirmed by long time variations in water levels which reveal the infiltration pattern of the natural cycle in urban areas [GLEICK et al. 2011; PALANIAPPAN, GLEICK 2009].

\section{ANALYSIS FOR GEOLOGICAL BEHAVIOUR}

On basis of literature review for rainfall runoff analysis suggested by BELLO et al. [2017] and RADECKI-PAWLIK et al. [2014] for SCS curve method of runoff simulation and $\mathrm{CN}$ method for un-gauged catchments producing hydrographs for rainfall runoff prediction, the simulation results for the study area were grouped and analysed by multiple regression for the best correlation of determination for the various groups. Also the SCS curve number was grouped soil wise to develop and correlation between soil and runoff pattern.

Observation of built-up and runoff correlation for group A (impervious soil). Group A consists of porous areas with roughness value of 0.05 to 0.17 and impervious areas with 0.011 to 0.012 . This group was simulated for runoff values at different catchments with other specifications being constant and the resulting runoff $\%$ was correlated with increasing built-up.

This group as in Figure 8 shows that for given roughness of impervious areas the coefficient of determination is 0.946. This shows that land cover with smooth asphalt as impervious surface and fallow soil with less grass does have a strong correlation for built-up and run off and do not favour recharge to the satisfactory level.

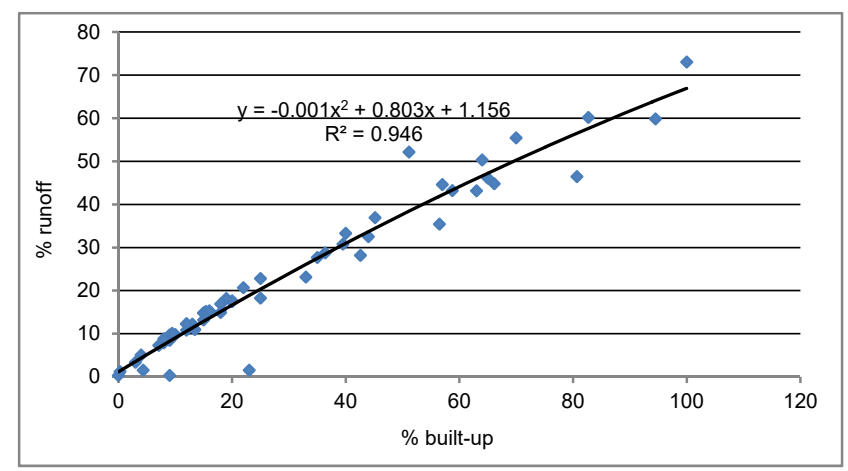

Fig. 8. Correlation between \% built-up surfaces and runoff for group A; source: own study

Table 3. Observation for infiltration and runoff for different land covers

\begin{tabular}{|l|c|l|c|l|l|l|}
\hline \multicolumn{1}{|c|}{ Land cover } & Roughness & \multicolumn{1}{|c|}{ Catchment } & Group & Land cover & Runoff result & Infiltration \\
\hline $\begin{array}{l}\text { Asphalt concrete with low to } \\
\text { medium grass }\end{array}$ & $0.011-0.013$ & $\begin{array}{l}\text { BCIC-S1, BSHC-S2, BSHC-S7, BSHC-S5 } \\
\text { BSHC-S1, BLPC-S2, BOCC-S2 }\end{array}$ & A & impervious & poor & low \\
\hline $\begin{array}{l}\text { Asphalt concrete with dense } \\
\text { bushes and forest }\end{array}$ & $0.05-0.60$ & $\begin{array}{l}\text { BSHC-S6, BSHC-S5, BSHC-S4, BLPC-S1, } \\
\text { BOBC-S1 }\end{array}$ & B & basalt & moderate & moderate \\
\hline $\begin{array}{l}\text { Low to medium grass with } \\
\text { mud concrete }\end{array}$ & $0.013-0.170$ & $\begin{array}{l}\text { BOBC-S3, BOCC-S1, BSHC-S7, BOBC-S2, } \\
\text { BOCC-S2 }\end{array}$ & C & sandstone & $\begin{array}{l}\text { moderate to } \\
\text { good }\end{array}$ & good \\
\hline $\begin{array}{l}\text { Dense bushes forest with } \\
\text { mud concrete }\end{array}$ & $0.24-0.81$ & $\begin{array}{l}\text { BLPC-S1, BSHC-S4, BSHC-S7, BLPC-S1, } \\
\text { BSHC-S6, BSHC-S10, BLPC-S1, BOCC-S3 }\end{array}$ & D & alluvial & very & very good \\
\hline
\end{tabular}

Source: own elaboration. 
Observation of built-up and runoff correlation for group B (basalt). This group observation reveals that combination of impervious land cover with roughness 0.011 to 0.12 and porous roughness with 0.05 to 0.60 having bushy land cover show strong relation for built-up and runoff having the coefficient of determination 0.931 as in Figure 9.

This is due to high-intensity rainfall which is not able to infiltrate in alluvial soil and basalt soil. Only the rate of evapotranspiration is controlled to some extent due to bushy vegetation, but infiltration needs suitable soil and land cover conditions.

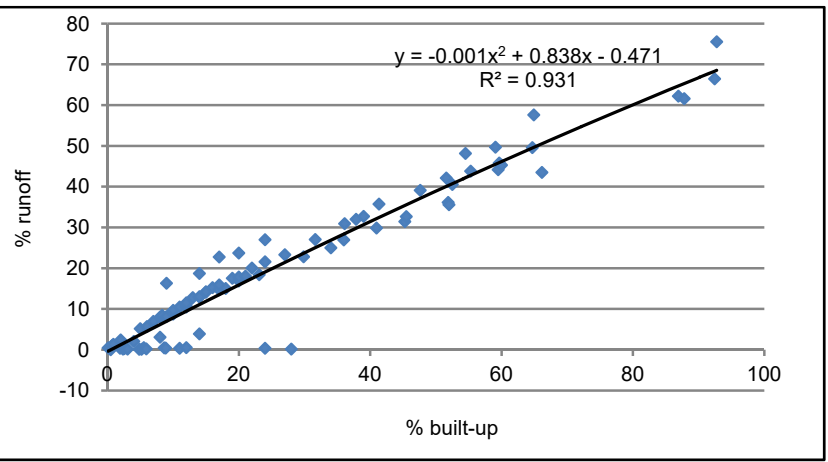

Fig. 9. Correlation between \% built-up surfaces and runoff for group B (basalt); source: own study

Observation of built-up and runoff correlation for group C (sandstone). This combination comparatively supports less runoff for increasing built-up having a combination of bushy land cover and grassy impervious cover with roughness from 0.004 to 0.05 (impervious surface) and 0.103 to 0.17 (pervious surface). The coefficient of determination is 0.862 . The existence of such land cover on alluvial and sandstone soil helps in reducing runoff volume as well as intensity to a great extent. Such land cover in accordance with built-up if inducted suitably on certain soil groups can show the higher percentage of recharge possibilities (Fig. 10).

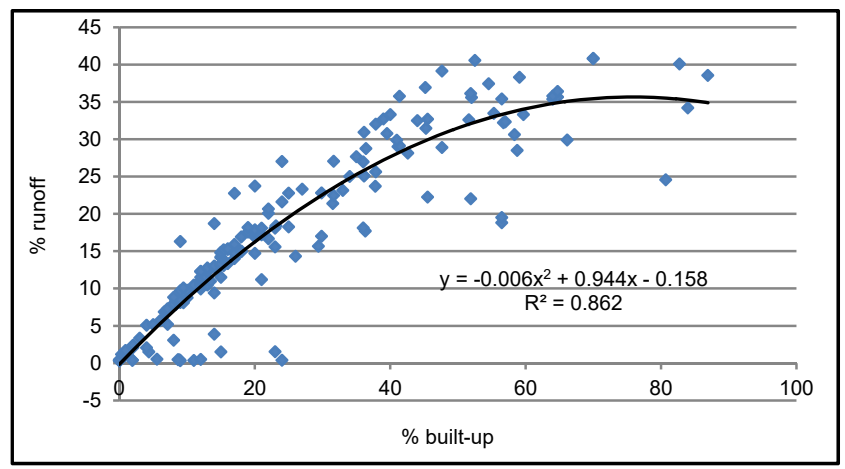

Fig. 10. Correlation between \% built-up surfaces and runoff for group C; source: own study

Observation of built-up and runoff correlation for group D (alluvial soil). Group D having the combination of bushy trees and fallow land with grass cover or natural soil with roughness from 0.04 to 0.05 (impervious surface) and from 0.24 to 0.81 (pervious surface) have runoff $\%$ increasing with increasing built-up supporting the combination for urbanization with certain conditions. The coefficient of determination comes to 0.920 as in Figure 11. Here the barren land and bushy land cover support recharge for urban areas. But since this type of land cover and natural areas are less available in urban areas, the percentage of recharge is less.

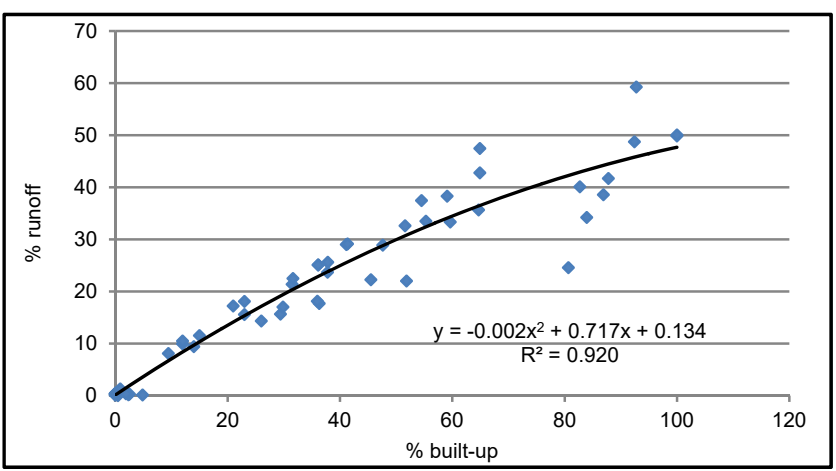

Fig. 11. Correlation between \% built-up surfaces and runoff for group D (alluvial soil); source: own study

\section{VALIDATION}

After getting these correlations from the actual and modelling it is necessary to validate the results of the data analysis to ascertain the efficiency of the results and the modelling procedure. Observing the results for various other combinations did validation and number of observation for temporal variations as well as spatial variations for selected roughness values and soil groups. These different values for different time intervals, different soil with different land covers and roughness are compared to the coefficient of efficiency or NSE coefficient. Calibrated and validated charts [RADECKI-PAWLIK et al. 2014].

Group A (impervious surfaces). Apart from individual observations for calibrated and validated results for variations in runoff, the whole study area was also observed for the confidence level of both results and it was found that coefficient for determination $R^{2}$ for both had almost same of 0.946 and 0.931 as shown in Figure 12 . Group A being impervious soil when subjected to the selected type of roughness values, clearly illustrates that runoff is directly proportional to built-up surface for highintensity rainfall as the alluvial soil has high infiltration

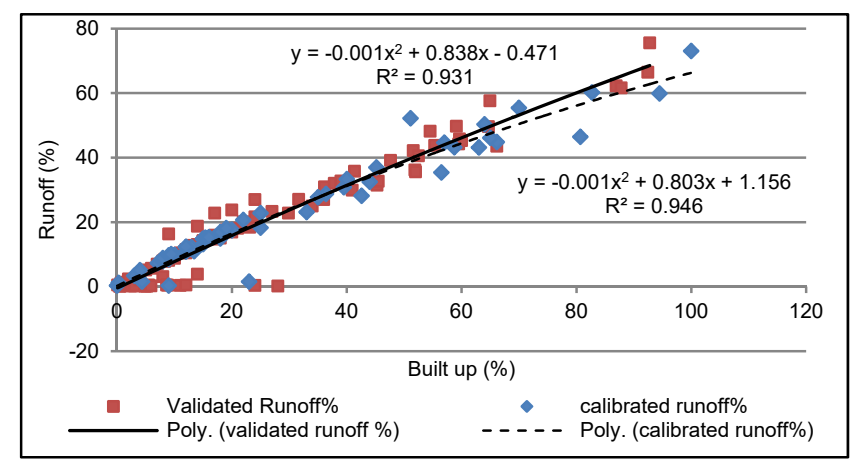

Fig. 12. Coefficient of determination for calibration and validation - group A; source: own study 
capacity for medium intensity rainfall [GRZYWNA, SENDER 2017; SHARMA 2017].

Group B (basalt). For basalt (group B) the coefficient of determination has the difference but within an allowable range having values of $R^{2}=0.862$ and 0.920 for validated and calibrated observations as shown in Figure 13. Since basalt has moderate water holding capacity allowing infiltration with a suitable land cover it helps in reducing runoff and helps infiltration. Suitable land covers help in urbanization processes with normal water cycle continuing in areas with alluvial and sandstone for roughness ranging from 0.11 to 0.41 including pervious and impervious surfaces.

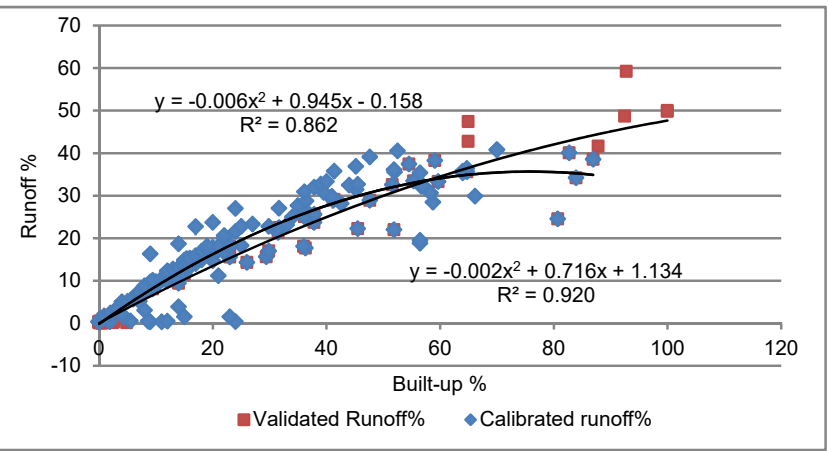

Fig. 13. Coefficient of determination for calibration and validation - group B; source: own study

Group C (sandstone). Group D as in Figure 14 consisting sandstone soil with dense forest, water bodies and vegetated land do have least efficiency in helping runoff over increasing built-up and coefficient of determination of 0.660 and 0.658 . Such natural areas if conserved in urban $40 \%$ of built-up induction and it is after this value that are runoff and built-up surfaces for calibrated and validated values as it does not support high-intensity precipitation till as having sandstone do help in forming recharge zones and thus helping in maintaining satisfactory water levels.

Group D (alluvial soil). Fourth group representing alluvial soil in Figure 15 shows the least correlation between runoff matches to built-up with coefficient determination of 0.828 to calibrated value of 0.985 having increase in

Table 4. Equation for scenario 1, 2, 3 and 4 (general)

\begin{tabular}{|l|c|c|c|c|c|}
\hline Type of soil & Roughness impervious & Roughness pervious & $\begin{array}{c}\text { Built-up } \% \\
(x)\end{array}$ & $\begin{array}{c}\text { Runoff \% } \\
(y)\end{array}$ & $\begin{array}{c}\text { Equation A, B, C, D for scenarios } \\
\text { given in Table 2 }\end{array}$ \\
\hline \multicolumn{7}{|c|}{ Scenario 1 } \\
\hline General & $0.011-0.012$ & $0.05-0.17$ & $0-99.98$ & $0.32-73.02$ & $y=-0.001 x^{2}+0.803 x+1.156$ \\
\hline \multicolumn{7}{|c|}{ Scenario 2 } \\
\hline Basalt & $0.011-0.12$ & $0.17-0.24$ & $0-92.75$ & $0.121-75.56$ & $y=-0.001 x^{2}+0.838 x+1.156$ \\
\hline \multicolumn{7}{|c|}{ Scenario 3 } \\
\hline Alluvial & $0.04-0.05$ & $0.24-0.81$ & $0-69.98$ & $0.32-40.85$ & $y=0.001 x^{2}+0.382 x+3.861$ \\
\hline \multicolumn{7}{|c|}{ Scenario 4 } \\
\hline Sandstone & $0.04-0.05$ & $0.24-0.81$ & $0-99.98$ & $0.01-59.24$ & $y=0.002 x^{2}+0.716 x+0.134$ \\
\hline
\end{tabular}

Source: own study.

Table 5. Nash-Sutcliffe coefficient of efficiency validation

\begin{tabular}{|c|c|c|c|c|c|c|c|}
\hline \multicolumn{2}{|c|}{ Equation A } & \multicolumn{2}{c|}{ Equation B } & \multicolumn{2}{c|}{ Equation C } & \multicolumn{2}{c|}{ Equation D } \\
\hline$R^{2}$ & $E$ & $E$ & $R^{2}$ & $E$ & $R^{2}$ & $R^{2}$ & $E$ \\
\hline 0.995634 & 0.997 & 0.991 & 0.99659 & 0.995223 & 0.997198 & 0.997098 & 0.99723 \\
\hline
\end{tabular}
Source: own study.

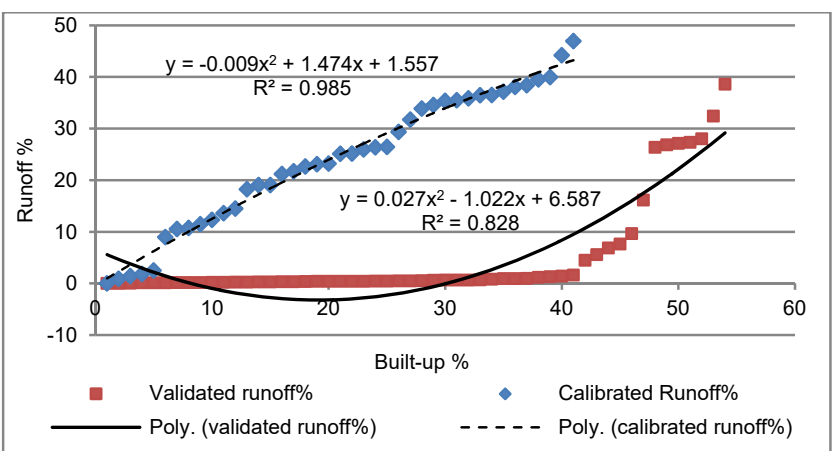

Fig. 14. Coefficient of determination for calibration and validation - group C; source: own study

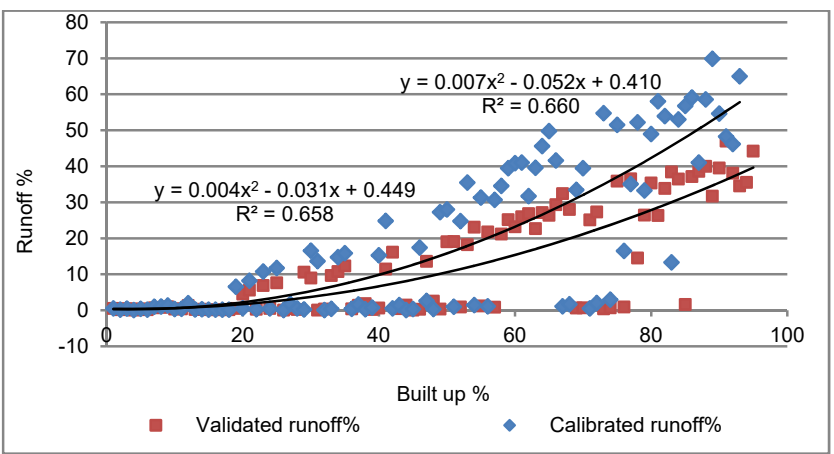

Fig. 15. Coefficient of determination for calibration and validation - group D; source: own study

runoff with initial $20 \%$ built-up. The infiltration characteristics of alluvial with minimum vegetation support recharge and allow less runoff to be generated for specific precipitation levels. The carrying capacity shows the good response of natural water cycle to urbanization.

\section{SUGGESTIONS}

Coefficient of determination and coefficient of efficiency (Nash-Sutcliffe coefficient of Efficiency $E$ ):

$$
E=1-\frac{\sum_{t=1}^{T}\left(Q_{o}^{t}-Q_{m}^{t}\right)^{2}}{\sum_{t=1}^{T}\left(Q_{o}^{t}-\overline{Q_{o}}\right)^{2}}
$$

This coefficient validation is shown in Table 5. 


\section{CONCLUSIONS}

Basalt. For Deccan basalt, parks and open space use are best suited and for loamy basalt commercial areas are well suited. For Deccan basalt roughness values range from 0.24 to 0.41 which indicates that areas having basalt should consist of vegetation ranging from scanty grass to bushes and also pervious open spaces in form of parks and greenbelts should be necessarily placed in planning to make a way as well interception of running water. The equation $y=-0.001 x^{2}+0.838 x+1.156$ will help to calculate the resulting runoff when actual built-up delineated after subtracting open spaces, Marginal open spaces, and other pervious areas. If still the percentage of runoff is more, the value of $y$ can be balanced by decreasing the value of $X$ until the runoff within limit is achieved. Suggested built-up induction is only $20-30 \%$ of total area. However, if still the runoff cannot be brought near or below natural range the given range of allowed runoff in the table can be achieved by more planning options of land uses with maximum connected pervious areas and unconnected impervious areas to discharge their runoff in open spaces nearby which helps in recharging the underground water. Runoff expected from basalt is around 50 to $60 \%$ which can be collected in natural areas or transferred to groundwater through pervious pockets in developed areas.

Alluvial. Though alluvial soil has the maximum water holding capacity, it has its limitation of penetrating water very slowly and water is penetrated it adds to the groundwater deep below. Hence alluvial soil is considered good for recharging with slow water running areas or for stagnant water. Still, equation $y=0.001 x^{2}+0.382 x+3.861$ have observed that when properly planned the alluvial soil can be inducted with $60 \%$ of built-up over it and remaining $40 \%$ needs to be planned very carefully with moderate vegetated land covers allowing runoff to run at very slow pace and passing through open spaces. Industries, residential areas with large open spaces are best to plan at an alluvial soil. Runoff pattern should be slow for these areas. The roughness values of 0.17 and 0.24 indicate the land cover with grass, small plants, hazes, herbs, normal vegetation, bushy trees etc.

Alluvial soil when planned should be given full opportunity to infiltrate precipitation as it will help in increasing the level of groundwater and recharging levels of the area.

In general, terms where soil type is not known, $20 \%$ of runoff can be adjusted by planning open spaces and pervious areas.

For basalt $30 \%$ of runoff can be easily saved by using scanty vegetation. Sandstone and alluvial soil allow saving runoff of about $15-35 \%$.

Sandstone. For sandstone, it can be concluded that it has less water holding capacity than alluvial but if given a suitable land cover it is best for recharging as well as controlling the runoff for the developed areas. The most suitable land use for sandstone is residential and since most of the planning modules and plans have maximum residential areas, the availability of sandstone as geology is considered best for development. With sandstone, a planner can go up to $70 \%$ built-up area of the total area and also play with remaining $30 \%$ area with land covers like scanty grass, bushes and following natural slope to counter the runoff and its flow in the suitable direction. The amount of runoff generated can be calculated from the equation $y=0.002 x^{2}+0.716 x+0.134$. Again the resulting runoff can be adjusted with the variations in the value of $x$. the value of $x$ can be achieved by using larger plot sizes with more marginal open spaces, with parks and playground near natural pathways, protecting them and using the extra floor area ratio proposal to get more open space on the ground to intercept the rainwater. The roughness value ranges from 0.05 to 0.41 means that plain concrete lining, scanty grass, barren land, vegetated land, agriculture land, and forest can be a part of sandstone areas to complement the natural processes with the development.

The resulting runoff is expected to range between 45 $50 \%$ and $70 \%$ of built-up induction

In planning residential areas over sandstone, the maximum use of the definition of open space should be assured, as open to the ground concept if targeted in residential areas we can control almost $40-50 \%$ of runoff generation and velocity through this. It is observed in the study area that most of the residential buildings had covered $63 \%$ more open spaces than allowed. So planning with policy and law can definitely help to bring the desired results in land cover allocation.

\section{REFERENCES}

Agvise Laboratories 2001. Water holding capacity [online]. Agvise.com, soil testing and laboratory services. [Access 15.07.2009]. Available at: https://www.agvise.com/ educational-articles/water-holding-capacity/

BĄK B., KUBIAK-WóJCiCKA K. 2017. Impact of meteorological drought on hydrological drought in Torun (central Poland) in the period of 1971-2015. Journal of Water and Land Development. No. 32 p. 3-12. DOI 10.1515/jwld-2017-0001.

Bello A.-A.D., HASHIM N.B., HANIFFAH R.M. 2017. Impact of urbanization on the sediment yield in tropical watershed using temporal land-use changes and a GIS-based model. Journal of Water and Land Development. No. 34 p. 33-45. DOI 10.1515/jwld-2017-0036.

CGWB 2010. Ground water scenario of India 2009-10. Faridabad. Central Ground Water Board pp. 45.

CGWB 2014. Bhopal water prospects [online]. Madhya Pradesh, Bhopal. Bhopal Centre Ground Water Board. [Access 10.01.2017]. Available at: http://cgwb.gov.in/Regions/NCR/ Reports/Status\%20of\%20Ground\%20Water\%20Level\%20 in $\% 20$ Mdhya $\% 20$ Pradesh $\% 20$ State $\% 20$ During\%20May2015.pdf

CWC 1988. Flood estimate report for Chambal Subzone-1(b). A method based on unit hydrograph principle. Design Office Report. No. C/16/1988. New Delhi. Directorate Hydrology (Small Catchment), Central Water Commission pp. $32+$ Append.

Environment, Heritage and Local Government 2009. Guidelines for planning authorities on sustainable residential development in urban areas (Cities, towns \& villages) [online]. Dublin pp. 79. [Access 10.01.2017]. Available at: https://www.housing.gov.ie/sites/default/files/migratedfiles/en/Publications/DevelopmentandHousing/Planning/File DownLoad\%2C19164\%2Cen.pdf

Fletcher T.D, Andrieu H., HAmel P. 2013. Understanding, management and modelling of urban hydrology and its 
consequences for receiving waters: A state of the art. Advances in Water Resources. Vol. 51 p. 261-79. DOI 10.1016/j.advwatres.2012.09.001.

GLEICK P. (ed.). 2011. The world's water. Vol. 7. The biennial report on freshwater resources. Island Press/Center for Resource Economics. ISBN 978-1-61091-048-4 pp. 424.

GRZYWNA A., SENDER J. 2017. Land cover changes in catchment areas of lakes situated in headwaters of the Tyśmienica River. Journal of Water and Land Development. No. 33 p. 65-71. DOI 10.1515/jwld-2017-0020.

HAMDI R., TERMONIA P., BAGUIS P. 2011. Effects of urbanization and climate change on surface runoff of the Brussels Capital Region: A case study using an urban Soil-Vegetation-Atmosphere-Transfer Model. International Journal of Climatology. Vol. 31. Iss. 13 p. 1959-1974.

IPCC 2007. Climate change 2007. The physical science basis: contribution of working group I to the fourth assessment report of the Intergovernmental Panel on Climate Change. Eds. S. Solomon, D. Qin, M. Manning, Z. Chen, M. Marquis, K.B. Averyt, M. Tignor, H.L. Miller. Cambridge, United Kingdom. Cambridge University Press. New York, NY, USA pp. 996.

KARMAKAR S. undated. Hydrologic simulation models [online]. Module 9. 5 Lectures. [Access 15.04.2017]. Available at: https://pl.scribd.com/document/170759014/Lecture-1

Marsbug 2007. Natural drainage systems as simple inorganic life [online]. [Access 26.07.2011]. Available at: https://forum. cosmoquest.org/showthread.php?90734-Natural-DrainageSystems-as-simple-inorganic-life \&s= 291554cb50f0dbab5814b1cf9de2d4d2

Monk E., Chalmers L. 2006. Mimic natural drainage processes a practical approach for stormwater management in Western
Australia [online]. 1st National Hydropolis Conference 2006 Burswood Convention Centre Perth, Western Australia. Department of Water Government of Western Australia p. 1-16. [Access 10.01.2017]. Available at: https://www.water.wa. gov.au/_data/assets/pdf_file/0018/5148/89891.pdf

RADECKI-PAWlik A., WaŁĘGA A., WoJKOWSKi J., PiJANOWSKi J. 2014. Runoff formation in terms of changes in land use Msciwojów water reservoir area. Journal of Water and Land Development. No. 23 p. 3-10. DOI 10.1515/jwld-2014-0024.

SAlvadore E., Bronders J., BatelaAN O. 2015. Hydrological modelling of urbanized catchments: A review and future directions. Journal of Hydrology. Vol. 529. P. 1 p. 62-81.

SHARMA S. 2015. Correlating urban system and hydrological system in the context of physical planning. International Journal of Scientific \& Engineering Research. Vol. 6. Iss. 4 p. $1334-1348$.

Sharma S., Bharat A., Das V.M. 2011. Quantitative analysis for change detection in water cycle working due to increasing built-up area induction in urbanization and guide lines for water. Innovations for Sustainable Management (March) p. 53-69.

Sharma S., Bharat A., DAS V.M. 2013. Statistical change detection in water cycle over two decades and assessment of impact of urbanization. Open Journal of Modern Hydrology, Scientific Research. Vol. 3 p. 165-171. DOI 10.4236/ ojmh.2013.34020.

UNESCO 2006. Water, a shared responsibility. The United Nations World Water Development Report 2 (WWDR 2) [online]. United Nations Educational, Scientific and Cultural Organization. ISBN 978-92-3-104006-1 pp. 584. [Access 10.01.2017]. Available at: https://unesdoc.unesco.org/ark:/ 48223/pf0000145405

\section{Sheetal SHARMA}

Powiązanie gleb i planowania urbanistycznego w aspekcie zrównoważonego obiegu wody

\section{STRESZCZENIE}

Modelowanie hydrologiczne za pomocą takich modeli, jak SCS Curve Number, HCS czy Pakiet Hydrologicznych Symulacji Fortran (HSPF) oraz kinematyczne modele falowe są obecnie powszechnie stosowane w różnych badaniach. Nadal jednak brak takiego modelowania w pracy urbanistów stojących wobec wyzwań, stawianych przez wielorakie oddziaływania heterogennych zlewni miejskich z systemami wodnymi. Sztuka planowania urbanistycznego i wdrożeń technicznych korzystających ze zmian reakcji wody na zlewnie miejskie jest potrzebą obecnego planowania miast. Złożoność efektów i zmiany w systemach wodnych lub miejskich zlewniach oraz niepełna znajomość tych interakcji skutkuje niepowodzeniami w zrównoważonym rozwoju miast. Planowanie miast wymaga metodologii wrażliwej na kwestie wodne, aby operacyjnie powiązać glebę, wodę i pokrycie gruntów z populacją ludzką. W pracy dokonano przeglądu planowania urbanistycznego wrażliwego na kwestie wodne $\mathrm{z}$ uwzględnieniem roli gleby w planowaniu relacji wody z lądem celem zidentyfikowania bieżących ograniczeń i możliwości przyszłego planowania.

Dostępność danych i uproszczone metody to nadal silne ograniczenie urbanistów. Dlatego hydrologia miasta bywa często upraszczana do badania spływów po nieprzepuszczalnych powierzchniach lub do hydrauliki systemów wodociągowych. Niniejsza praca prezentuje sposób podejścia i uniwersalne rozwiązanie służące prognozowaniu zachowania zlewni miejskiej w reakcji na urbanizację w odniesieniu do naturalnej relacji ląd-woda i ich zastosowanie w planowaniu istniejących bądź nowych zlewni miejskich. Metodologia polega na obserwacji 19 zlewni miejskich o różnych typach gleb i zabudowy. Szczegółowe analizy poziomów wody w studzienkach hydrologicznych i schematu spływów wody w okresie 40 lat dostarczyły danych do wyprowadzenia liniowej korelacji między rodzajem gleby, szorstkością podłoża, pokryciem powierzchni ziemi, infiltracją, wodami podziemnymi, wszystkie powiązane z właściwościami gleb. Te korelacje umożliwiły ustalenie równań regresji stanowiących schemat dla przyszłych norm planowania urbanistycznego do wykorzystania przez planistów, inżynierów i hydrologów.

Słowa kluczowe: geologia, obieg wody, planowanie urbanistyczne, pokrycie gruntu, spływ, użytkowanie ziemi 